\title{
O skupnostnem izobraževanju in razvoju kraja
}

\author{
Dušana Findeisen
}

\begin{abstract}
»Skupnost je vse tisto, kar ljudi povezuje, in ne tisto, kar dela posameznike različne."
\end{abstract}
Skupnostno izobraževanje znova pridobiva vrednost. Pa ne le zato, ker mnoge države ne vedo več, kako s sedanjimi institucijami zadovoljiti mnoge nezadovoljene potrebe ljudi. Najverjetneje je skupnostno izobraževanje del nezadržne demokratizacije, ki jo doživlja svet. Odnosi med ljudmi postajajo bolj horizontalni, manj hierarhični. Ljudje se povezujejo med seboj in izmenjujejo znanje. Po znanje ne hodimo več toliko na mesta, kjer lahko znanje dobimo: v knjižnice, laboratorije, na univerzo. Znanje potuje $\mathrm{k}$ nam. Prinašajo ga CD-ROM-i, Internet, s katerim se povezujemo z ljudmi. Na Internetu se srečujejo ljudje in posamezna področja. Podobno pa s skupnostnim izobraževanjem ljudje najdemo rešitve za svoje probleme tam, kjer živimo. O njih ne odloča oddaljena oblast. Odločamo sami.

»Vsaka koncentracija denarja ali znanja pomeni, da je v ozadju lastnik. $\ll^{1} \mathrm{~S}$ sodobnimi multimedijskimi sredstvi lastnika ni in $\mathrm{v}$ tem je prava demokratizacija. Tudi v skupnostnem izobraževanju lastnika znanja ni, saj dajemo znanje drugim ljudem. Ne gre le za to, da si izmenjujemo znanje. Spreminjamo ga v skupno delo, ki naj bi izboljšalo naše življenje, rešilo nekatere od naših skupnih problemov, zadovoljilo naše interese in potrebe in prispevalo k razvoju naše skupnosti ali našega kraja.

\section{Spremembe okrog nas ali nova vloga dela}

Skozi zgodovino se vloga dela spreminja. Delo je bilo dolgo sramotno, $v$ dvajsetem stoletju pa je iznenada postalo utelešenje normalnosti. Imeti delo je $\mathrm{z}$ moralnega gledišča pomenilo, in še danes pomeni, imeti družbeno dostojanstvo ali kot pravimo socialni status. Že več kot petdeset let je tako življenjski ciklus moških in žensk naravnan po delu oziroma službi. Nekdanji brezdelneži so izginili, pa naj so to bili brezdelneži z dna družbene lestvice, kot so potepuhi, berači, ali pa bogataši in rentniki z njenega vrha.

Delo je imelo še prav poseben pomen v nekdanjih socialističnih državah. »Delu čast in oblast« smo prebirali parole, napisane po stenah. Vseživljenjsko izobraževanje smo dojeli kot »izobraževanje ob delu«. Na cesti smo se pozdravljali: »Kje pa si zdaj?« »Kje« je pomenilo, v kateri ustanovi ali katerem podjetju. Da bi dobili službo, smo šli študirat na fakulteto, o ustvarjanju družine pa smo razmišljali šele takrat, ko smo se prvič zaposlili za nedoločen čas. Od plače smo odvajali razne zavarovalnine, da bi bili zavarovani, če bi postali invalidni ali imeli nesrečo. Višina plač je narekovala višino naše pokojnine. Država je v našem imenu razporejala sredstva med aktivnimi in neaktivnimi generacijami. In vse je nekako šlo.

\section{Model v krizi}

In vendar! Ta družbeni model je danes v krizi. Internacionalizacija in terciarizacija gospodarstva $\mathrm{v}$ državi zmanjšujeta možno-

${ }^{1}$ Francoski filozof Michel Serre o tem razmišlja v reviji Telerama. sti, ki smo jih imeli prej. Čim manj je dejansko pobranih davkov, tem manj lahko država vpliva na višino obrestnih mer, manj lahko stori v zvezi s socialnim varstvom. Naenkrat postaja vključitev v družbo na podlagi službe vprašljiva. To seveda ne pomeni, da bodo službe kar izginile. Še zmeraj bodo ostale pomemben nosilec družbene samopodobe posameznika, vendar še zdaleč ne tako pomemben kot nekoč.

Čas je, da pogledamo spremembam v oči. Mnogi si še dandanes želijo službe s polnim delovnim časom in za nedoločen čas. Takšne želje so sicer upravičene, pa vendar! Politiki so si večinoma prizadevali, da bi za to, da bi ljudje imeli službe, naredili nemogoče. Dolga leta ohranjamo pri življenju železarne, ki goltajo denar, obutveno industrijo, ki še zmeraj ni uspela spremeniti svojih proizvodnih postopkov v skupinsko delo, niti svojih proizvodov prilagoditi drugačnemu okusu, mi pa podpiramo in plačujemo njene izgube. In vendar, kakšen rezultat prinaša takšna politika, ki obrača pogled v prihodnost, oči pa so ji pripete na preteklost? Tako le potrjuje današnji negotov položaj zaposlitve. Če smo pošteni in etični, moramo ugotoviti, da številni ukrepi za ohranjanje delovnih mest niso preprečili niti nezaposlenosti niti nedejavnosti množic. V Sloveniji imamo samo upokojencev 453.000 in več kot 100.000 nezaposlenih. Tem se pridružujejo še mladi, ki iščejo prvo delovno mesto. Mnogi ljudje, tudi tisti z znanjem, ki ga tako primanjkuje, so predčasno upokojeni.

\section{Kriza zahfeva novo razmerje med državo in civilnim sektoriem}

V Sloveniji in drugih postsocialističnih državah se vloge javnega, zasebnega, in še posebej civilnega, sektorja oblikujejo na novo. Zdaj je nedvomno čas, da dosežemo primerno razmerje med državo in civilnim sektorjem. Čas je, da se opremo na smiselne lokalne rešitve in jih ne podrejamo logiki državne politike. Zaradi povezave med državnimi ukrepi in socialnovarstvenimi ukrepi v zvezi z delovnimi mesti se je povečala množica statusov nezaposlenih ali vmesnih statusov, ki nihajo med delom (javnim delom) in socialno pomočjo. Osnovno varnost naj bi zagotovilo nadomestilo za nezaposlenost. Zahodnoevropske države, ki svojo krizo nezaposlenosti prebivalstva doživljajo še težje, so uvedle mnoge polovične oblike zaposlovanja, namenjenega predvsem ranljivim socialnim skupinam, kot so ženske in mladi. Te polovične rešitve naj bi jim pomagale najti pot k stalni zaposlitvi. Sem spadajo solidarnostne službe, ki spominjajo na naša javna dela, ki naj bi tem ljudem odprle pot v podjetja. Navadno pa se to ne zgodi. Enako velja za pripravništvo. Pripravnik svoje obdobje pripravništva konča in takrat njegov delodajalec zaposli novega pripravnika, in tako gre v nedogled. Pri tem se pojavljajo tudi druge oblike subvencioniranih delovnih pogodb. Kakšna pa je psihološka škoda, ki tako nastane pri mladih ljudeh, pa ne vemo prav natančno.

Vse te »rešitve« država uporablja, čakajoč na povratek gospo- 
darske rasti, ki naj bi ustvarila delovna mesta. In še zmeraj nas spremlja prepričanje, da se ljudje lahko dobro socializiramo, in zares socializiramo, le na delovnem mestu. Še vedno smo prepričani, da socializacija poteka po logiki »daš-dam«. Tako vsi ti ukrepi zaposlitvene politike, ki naj bi bili začasni, vendar kaže, da postajajo stalni, silijo nezaposlene v negativna psihološka stanja, v iskanje zaposlitve, ki je ni. Ta položaj je nedvomno neugoden in povzroča negativizem ter kvarno vpliva na motivacijo ljudi.

Zaposlitvene politike so bile v zadnjih letih v vseh državah neuspešne, razen v ZDA, kjer so šle na račun usodnega znižanja že tako najnižjih dohodkov. Tako so dohodki 20 odstotkov najrevnejših Američanov doživeli petodstotno znižanje. Iz vsega tega lahko sklepamo: odslej ne bo več zaposlitve, ki bi trajala celo življenje. Tako se bomo morali vprašanja nezaposlenosti in njenega reševanja lotiti drugače. Enako verjetno ni rešitev nastalega položaja v tako imenovanem obveznem delu vseh, ki so dve leti prejemali denarno nadomestilo, vendar niso našli zaposlitve. To bi bila oblika kaznovanja iskalcev zaposlitve, z vsemi negativnimi posledicami. Takšno obliko predlaga Amerika in nekatere evropske države jo poskušajo posnemati. Vse pogosteje namreč slišimo, da ni pravic brez obveznosti. O tem začenjamo govoriti tudi v zvezi z upokojenci, katerih število se nezadržno veča, tudi v povezavi s hendikepiranimi in težko zaposljivimi ljudmi itd. Temelji družbe naj bi se zamajali zato, ker so razmerja med pravica$\mathrm{mi}$ in obveznostmi porušena.

\section{Na kalterih mačelih temelji družba}

Družbe, ki so organizirane na podlagi stalne zaposlitve, delujejo po mešanem načelu svoboda-obveza-prisila. Človek lahko svobodno izbira delo, vendar to pogosto počne iz potrebe in tako pristaja na prisilo. Te družbe delujejo po načelu »dam-dobim«. To je načelo tržnega gospodarstva in države, od katerega težko odstopimo.

$\mathrm{V}$ družbah, ki ne bodo več mogle biti tako organizirane, se bo verjetno uveljavil drug princip: princip dajanja in darovanja drugim ljudem. Ta princip vsebuje svobodo in obvezo do drugih ljudi, vendar pa ne pozna prisile. Svoboda je močnejša od obveze in to ustvarja nova razmerja med ljudmi. Načelo dajanja ali darovanja drugim sicer ni načelo, ki lahko nadomesti načelo, na katerem temelji država, vendar je bistveno načelo za oblikovanje prave demokracije. Ta izhaja $\mathrm{z}$ vrednot, kot so sodelovanje, solidarnost, prispevanje, odgovornost, delovanje. V takšni obliki demokracije nismo podrejeni »računovodskemu obravnavanju pravic in dolžnosti, posojil in dolgov«. Še več, samo načelo in duh dajanja ter darovanja lahko spodbujata prostovoljna prizadevanja državljanov. Zdajšnje krize in zdajšnjih sprememb tako ni mogoče preživeti s tehničnimi rešitvami in z ukrepi. Ta kriza zahteva novo družbeno pogodbo, v kateri bo demokracija sama sebi cilj.

Posamezne države sicer sprejemajo zakone in uvajajo nekakšne oblike solidarnosti, na primer fondacije, prispevek za socialno varnost itd., vendar je takšna solidarnost abstraktna, kot je za ljudi abstrakten zakon, ki jo določa. Zakaj? Zato ker ni medosebnih razmerij, $\mathrm{v}$ katerih sodelujemo $\mathrm{z}$ dajanjem in ki oblikujejo našo pripadnost skupnosti.

$\mathrm{V}$ postsocialističnih deželah se, razen z zmanjšano gospodarsko rastjo in vsemi njenimi posledicami, srečujemo tudi s spremembo političnega sistema, $z$ drugačnim načinom proizvajanja in trženja, z za nas občutnim padcem državne blaginje. Ostajajo nam ljudje. Ti pa, tako pravijo v nekaterih vzhodnih državah, morajo oblikovati novo osebnost. Naučiti se morajo samostojno, ali v sodelovanju z drugimi, reševati probleme, si pridobiti ustrezno znanje za reševanje problemov, ki nastajajo v drugačni ekonomski in socialni stvarnosti, in o drugačnih političnih odloči- tvah države, v kateri živijo. Naučiti se morajo odločati. Sodelovati z oblastjo, še posebej pa $\mathrm{z}$ lokalno.

Dandanes se cela vrsta odgovornosti, ki spadajo v pristojnost države, prenaša na ljudi. Če je poprej država sprejemala odločitve o zdravstvenem varstvu ljudi, se morajo danes ljudje boriti za to, da mnoge pravice vsaj obdržijo. Za to, da lahko začnejo dialog z državo, pa potrebujejo znanje. Znati morajo sporočati javnosti, znati se morajo organizirati. In ne smejo dovoliti, da jih onemogoči birokratska logika. Vedeti morajo, da imajo pravico vedeti, prositi, zahtevati, sodelovati. Za vse to pa je potrebno znanje.

Mnogi ljudje danes začutijo probleme in vedo, da bi bilo treba nekaj narediti. Manjše število med njimi jih čuti, da so poklicani, da nekaj naredijo. Če ne naredijo, ker nimajo dovolj znanja, časa ali poguma, dobijo občutek krivde. Vendar lahko posameznik pri tako širokih vprašanjih, ki jih je poprej zmeraj urejala država, kaj malo naredi sam. Za večino svojih interesov in potreb človek ne bo mogel poskrbeti sam. Moral se bo naučiti delovati v skupnosti.

$\mathrm{V}$ vseh teh razmišljanjih smo našli podlago za razvoj skupnostnega izobraževanja za lokalni razvoj.

\section{Kaj je skupnost}

Skozi zgodovino je imela skupnost v različnih obdobjih zelo različen pomen. Včasih jo kujejo visoko v nebo, drugič spet gledajo nanjo zviška. Danes je pojem skupnost pojem, ki ga zaradi preteklih pomenov mnogi podzavestno zavračajo. Skoraj bi lahko trdili, da smo bolj naklonjeni individualizmu, iskanju svoje nove podobe $\mathrm{v}$ spremenjenih okoliščinah, potrjevanju samega sebe. Zdi se, kot da za skupnost nimamo dovolj moči. Za mnoge skupnost ne obstaja. Tudi pojem družbe je zamegljen. Zato se vprašajmo: »Kaj je dobra družba? Kaj je dobra skupnost?« V naših očeh je dobra družba oziroma skupnost tista, ki prepozna potrebe in skuša uporabiti spretnosti ter znanje vseh državljanov za skupnost kot celoto. Toda dobro je vedeti, da večino skupnosti opredeljujejo skupne značilnosti njihovih članov in skupni interesi, ki jih imajo člani in ki jih med seboj povezujejo.

Ena od skupnih značilnosti je lahko tudi to, da ljudje živijo skupaj v majhnem kraju ali mestni četrti. Skupni interesi pa so na primer:

- kulturna dediščina, skupna tradicija, skupna identiteta ljudi $\mathrm{v}$ kraju, pripadnost in zvestoba kraju;

- socialne vezi v soseski ali kraju, solidarnostna pomoč, druženje, ki temelji na podobnosti ljudi, na tem, da bivajo skupaj, na skupnih izkušnjah in težavah;

- prizadevanje za skupno politično moč, skupno delovanje za spremembe v sodelovanju $\mathrm{z}$ društvi, ustanovami, s podjetji, $\mathrm{z}$ lokalno oblastjo.

V zvezi s skupnostjo se pojavljajo nekateri koncepti, ki so zanjo značilni.

Prvi in najpomembnejši koncept je ta, da je ključ za rešitev problemov posamezne skupnosti v skupnosti sami. Pri tem verjamemo, da imajo ljudje dosti znanja, ki ga je treba prenesti tudi na druge. Posamezna skupnost ima tako lahko zelo dobro zdravstveno ustanovo, pa vendar bo zdravje ljudi v kraju boljše, če bodo ljudje svoje zdravje sposobni razumeti in ga uravnavati. To bodo lahko počeli sami, vendar jim bo dosti lažje, če se bodo združili z drugimi ljudmi. Tako nastanejo skupine za samopomoč bolnikov in njihovih družin ali društva, na primer pljučnih bolnikov, itd. Razen osnovnega namena takšna skupnost zadovoljuje še mnoge druge življenjske potrebe svojih članov.

Drugi koncept je v tem, da je treba ljudi pripraviti na to, da sodelujejo pri odločanju. Pri tem gre za osveščanje tistih, ki upora- 
bljajo posamezne storitve. To pomeni, da tisti, ki storitve uporabljajo, lahko med njimi izbirajo, da je na voljo več teh storitev in da niso prisiljeni izbrati posamezno storitev. Tisti, ki storitve uporabljajo, jih morajo jasno dojeti, spoznati njihov pomen za svoje življenje, pri čemer morajo biti takšne storitve dosegljive vsem. Če želijo na primer ljudje v posamezni občini dobiti podatke o delovanju občine, morajo biti ti podatki dosegljivi in pri roki, napisani v vsem ljudem razumljivem jeziku. Občinska vrata morajo biti odprta vsem. Občinski možje tako ne morejo človeka odpraviti na vratih, rekoč: »Če kaj želite, napišite prošnjo.« Ljudje morajo biti pripravljeni na to, da sodelujejo pri odločanju in spreminjanju stanja, da ne pristanejo na pogostni odgovor: »Ja, kaj hočete, tako je.« ali pa »Saj se tako ne da ničesar narediti.«

Državljani morda ne potrebujejo posamezne storitve, vendar imajo pravico o njej odločati. Pripravljati državljane na to, da imajo pravico soodločati, pomeni pripraviti jih na to, da vedo, da imajo pravico vedeti, pravico do pojasnila, pravico, da jim prisluhnejo, da jih poslušajo. To so osnovne pravice, za katere morajo državljani vedeti.

Skupnost državljanov je skupnost ljudi in presega posameznikove potrebe ter interese. Gre za tiste potrebe in interese, ki so skupni ljudem, ki tudi živijo skupaj na posameznem področju. V vsaki skupnosti se pojavljajo interesi, ki so skupni njenim članom. Pa ne samo interesi, marveč tudi pogledi, ki jih je v pogovoru mogoče prepoznati. Posamezne skupnosti so lahko kolektivne porabnice storitev, ki jih omogoča država, lahko pa želijo biti skupnosti, ki dajejo tem storitvam podobo, ki okolje oblikujejo, ki spreminjajo lokalni način življenja, ki dajejo svojemu kraju podobo. Taka priprava skupnosti na soodločanje pomeni, da ji omogočimo, da prepozna in opredeli tista vprašanja, ki so pomembna za življenje v kraju. Takšna pomembna vprašanja je mogoče izluščiti in opredeliti z občinskimi sveti, raznimi forumi, ki potekajo $\mathrm{v}$ soseskah itd. Seveda pa ima takšno podpiranje skupnosti tudi slabo stran, saj lahko včasih tudi grobo nasprotuje željam posameznikov.

Tretji koncept je koncept državljanskosti. Francozi pravijo, da se človek rodi kot državljan, dejaven državljan pa šele postane in za to potrebuje znanje. Državljanskost nima nič opraviti s suhoparnim znanjem o lokalni oblasti, parlamentarnih postopkih in na splošno o delovanju institucij. Državljanskost ljudi se ne izkazuje $\mathrm{s}$ tem, da prevzemajo predsedniške funkcije v klubih ali društvih. Gre preprosto za sodelovanje, ukrepanje, prispevanje, odgovornost, solidarnost.

Četrti koncept je v tem, da je skupnost od vseh bolj sposobna izrabiti vire, materialne in duhovne, ki jih ima na voljo, saj z njimi ravna zelo razsodno.

Peti koncept, na katerem temelji pojem skupnosti, je v povezavi $z$ ljudmi in njihovimi potrebami. Vsak član skupnosti ima potrebe. Nekateri imajo svojske, posebne potrebe (na primer invalidi), vseeno pa bodo morali k skupnosti tudi oni prispevati. V zvezi s tem mora animator ali skupnostni izobraževalec pripraviti ljudi, da odkrijejo, kaj ali kaj posebnega lahko skupnosti prispevajo.

\section{Razvoj skupnostnega izobraževanja v svelu}

To izobraževanje izhaja $\mathrm{z}$ anglosaške različice francoske socio-kulturne animacije. Že sama primerjava pove, da tudi skupnostno izobraževanje temelji na animaciji ljudi za izobraževanje in delo v skupnosti ter zunaj nje.

Če v francoski socio-kulturni animaciji še lahko govorimo o tem, da se začenja s Condorcetovim načrtom za javno učenje, pa je prave začetke skupnostnega izobraževanja težko odkriti. Danci so na primer prepričani, da se skupnostno izobraževanje pri njih začenja $\mathrm{z}$ dolgoletnim razvojem ljudskih visokih šol, ki poteka že več kot dvesto let. Britanci menijo, da je začetek skupnostnega izobraževanja pri njih pravzaprav v večernih šolah, ki so se pojavile na prelomu iz devetnajstega $v$ dvajseto stoletje. V Sloveniji pa lahko nedvomno posežemo nazaj v obdobje čitalnic in številnih prosvetiteljskih društev. Raziskovanje krajevne zgodovine nam marsikje odkrije kar številne skupnostne organizacije, na podlagi katerih se je izboljševalo življenje v kraju.

Skupnostno izobraževanje ima za seboj dolgo pot in težko bi rekli, da je zdaj napočil njegov čas. S filozofskega gledišča je to še zmeraj koncept, ki nastaja, čeprav ima za seboj dolgo zgodovino.

Morda se skupnostno izobraževanje izraziteje začne v ZDA v Flint Michinganu leta 1930, to je med množično nezaposlenostjo, in sicer na pobudo učitelja Franka Manleya, ki ga je zelo skrbela usoda mladih v njegovi regiji, tako da je ustanovil prvo skupnostno šolo. Temu se je pridružil človekoljub Charles Stuart Mott. Tako je tedaj nastala Mottova fondacija za skupnostno izobraževanje in začele so se prve korenite spremembe v izobraževanju v ZDA ter zunaj te države. ZDA so tudi edine, ki so uzakonile skupnostno izobraževanje, in sicer leta 1974 z Zakonom o skupnostni šoli, da bi tako zagotovile nastanek takšnih šol v celotni državi.

To gibanje se je razvijalo silno hitro, morda zato, ker se ni začelo v podeželskih skupnostih kot v Veliki Britaniji, temveč v zvezi z nezaposleno množico mladih. Čeprav so šole sprva dajale le prostore in drugače materialno omogočale razvoj skupnostnega izobraževanja, pa se je njihovo skupnostno delovanje kmalu razširilo na socialno varstvo. Tako so šole kmalu zadovoljevale potrebe skupnosti pri predšolski vzgoji, skrbele za povezavo s starši in za njihovo izobraževanje za njihovo starševsko vlogo. Zadovoljevale so potrebe starejših ljudi v kraju, se lotevale problemov v okolju in vprašanj mladih prestopnikov. Pravzaprav so se ukvarjale z vsemi potrebami, ki so se pojavljale v skupnosti. V skupnostnih šolah je začel tudi šolski program potekati sredi življenja. Mladi so se učili o samih sebi in o svojem okolju. Spoznavali so svojo zgodovinsko vlogo v danem geografskem okolju, pa tudi vprašanja družbene, duhovne in druge narave. Vir učenja je postalo fizično okolje v kraju, starši in drugi odrasli v skupnosti, ki so postali del učnega procesa.

V Veliki Britaniji so na skupnostno izobraževanje prav posebej ponosni. Začetke pripisujejo Henryju Morrisu, tajniku za izobraževanje v neki angleški pokrajini, ki je leta 1925 napisal za svoj odbor poročilo, s katerim je vplival na spremembo stanja v svoji pokrajini, pa tudi v drugih pokrajinah in zunaj Anglije. Med svojim delovanjem je namreč Morris spoznal, da »(...) so življenje, moč in podvzetnost počasi zapustili deželo. Že več kot sto let najvitalneši ljudje odhajajo $\mathrm{z}$ dežele, iz vasi. Zapuščajo kmetije in odhajajo v tovarne, delavnice in podjetja v mestih «.

Tako je Morris spoznal, da je »blaginja podeželske skupnosti odvisna od kakovosti izobraževanja, ki ga je mogoče prebivalcem ponuditi«. Morrisa je zanimala šolska mladina. Pa ne le ona, tudi odrasli. Uredil je dotrajane šolske prostore, poskrbel za skupne prostore, telovadnico, prostore za učenje obrti, ob večernih urah pa je iste prostore odprl odraslim. Ob večerih je šolsko predverje postalo rekreacijski prostor za vaščane, pa tudi prostor za druženje. Šolsko knjižnico so odprli za celotno vaško skupnost.

Pri takšnem delovanju je seveda razumljivo, da je Morris tako zgodaj razmišljal o vseživljenjskem izobraževanju. »Ko bo skupnostno središče zadoščalo potrebam vseh ljudi v soseski, bo zbrisana dvojnost vsakdanjega življenja in izobraževanja. Skupnostno središče bo postalo kraj, kjer se uči umetnosti življenja, pa tudi prostor, kjer je mogoče življenje živeti, « je zapisal. 
Morrisova prizadevanja so privedla do razvoja vaških kolidžev. Prvi je nastal šele leta 1930, pet let po Morrisovem poročilu. V drugih krajih so kasneje odprli podobne skupnostne šole ali skupnostne kolidže, kot so jih imenovali. Koncept skupnostnega kolidža pa so dosti kasneje, leta 1960, prenesli v mesta. Danes je v Veliki Britaniji približno 750 skupnostnih šol in kolidžev.

In kaj danes naredi iz šole skupnostno šolo? Da bi mladim vcepili zavest o vrednosti vseživljenjskega izobraževanja, moramo v šolo pripeljati starše in člane skupnosti. Sodelujejo naj pri učenju in poučevanju. Če otroci v šoli vidijo le svoje učitelje, potem so šole le otoki, osamljeni in oddaljeni od življenja in skupnosti.

Učitelji in šolsko osebje morajo razviti sposobnost sporazumevanja s starši, da bi se tako lahko med njimi razvil smiseln dvogovor. Tako v mnogih šolah že uporabljajo metode za uvajanje odraslih v življenje šole. Naj naštejemo nekatere med njimi:

- skupine prostovoljcev lahko otrokom pomagajo pri nalogah;

- odrasli dajejo otrokom informacije o poklicih, ki jih opravljajo;

- odrasli otroke učijo spretnosti za reševanje problemov;

- odrasli sodelujejo v pripravi zunajšolskih dejavnosti;

- odrasli pomagajo učencem $\mathrm{z}$ učnimi težavami;

- v razredih gostujejo strokovnjaki;

- učenci, ki se zanimajo za različne poklice, si med odraslimi najdejo mentorja;

- odrasli prostovoljci učijo otroke tehniških spretnosti itd.;

- otroci se vključujejo v socialno dejavnost v okolju (pomoč ljudem v stiski itd.).

Mnoge šole so začele v našem okolju uvajati v svoje delo nekaj teh dejavnosti. Nekaj spodbud se je pojavilo pri nas tudi z mednarodno maturo, pri kateri je eden od predmetov povezan $\mathrm{z}$ delom v skupnosti oziroma s pomočjo ljudem v stiski. Na neki mariborski gimnaziji so se takšnega dela lotili prav posebej učinkovito. Povezovali so se $\mathrm{z}$ raznimi ustanovami za socialno delo $\mathrm{v}$ kraju, otroci so se učili razumevati kulturo drugačnih ljudi, hendikepiranih, ljudi v stiski, starejših itd.

Šole se tako lahko preoblikujejo v izobraževalna skupnostna središča, ki so namenjena množici generacij in potreb. Skupnostna šola deluje vse leto in ponuja gostoljubje funkcionalno nepismenim ali pa kulturnim dejavnostim, pa tudi alternativnemu izobraževanju, ki je drugačno od predpisanega med letom.

Primer takšnega sodelovanja šole $\mathrm{z}$ okoljem je tudi povezava otrok in študentov slikarstva $\mathrm{z}$ Univerze za tretje življenjsko obdobje, ki so v Ljubljani pripravili skupno slikarsko razstavo s temo Moje Trnovo. Šlo je za skupno učenje več generacij, za sodelovanje $\mathrm{z}$ okoljem in za uvajanje kulture $\mathrm{v}$ šolsko okolje; tiste kulture, ki poglobi in oplemeniti naš pogled na to, kar nas obdaja.

\section{Razvoj kraja s sodelovanjem skupnosti}

Tradicijo razvoja kraja s sodelovanjem skupnosti poznajo $\mathrm{v}$ mnogih predelih sveta. Dosti je bilo pobud, s katerimi so si ljudje sami in s samopomočjo želeli zagotoviti razvoj ali oživitev svojega kraja. V mnogih državah vlade podpirajo takšna prizadevanja, že leta 1947 pa so jih priznali tudi Združeni narodi, ko so ustanovili posebno enoto, ki se ukvarja $\mathrm{z}$ vprašanji krajevnega razvoja $\mathrm{s}$ sodelovanjem skupnosti v državah v razvoju.

V Veliki Britaniji je gibanje za razvoj kraja s sodelovanjem skupnosti posledica razvoja krajevnih svetov za socialno delo. Njihov cilj je bil uskladiti socialne storitve na krajevni ravni. Gibanje za razvoj kraja je bilo sprva v tesni zvezi s socialnim delom, ki je bilo namenjeno ljudem v posameznih skupnostih. V Angliji je takšno gibanje nastalo s postavitvijo naselij na zaostalih področjih, da bi izboljšali življenje ljudem. Na Severnem Irskem se je gibanje za razvoj kraja razvilo iz tako imenovanih zglednih vasi. V zadnjih tridesetih letih pa je imela britanska vlada $v$ gibanju za razvoj kraja s sodelovanjem skupnosti pomembno vlogo.

V medvojnem obdobju so tako nastala številna društva, kot odziv na porajajoče se socialne težave $\mathrm{v}$ novih stanovanjskih naseljih. Ta društva so kasneje gradila skupnostna središča, ki so danes razširjena skorajda vsepovsod. V zadnjih petnajstih letih je na razvoj kraja s sodelovanjem skupnosti močno vplival razvit neprofitno-volonterski sektor. Prostovoljne organizacije se odzivajo na lokalne potrebe in tako so spoznali, da so potrebne spremembe v zakonodaji, upravnih strukturah in spremembe socialnih in ekonomskih dejavnikov. V zvezi s tem se je oblikovalo tudi prepričanje, da pobude, ki prihajajo iz skupnosti, niso zgolj začasne, inovativne, marveč postajajo pomembne za boljše sprejemanje nenehnih sprememb.

Neprofitno-volonterske organizacije so povzročile dvome o konceptu skupnosti in njene prilagojenosti hitrim spremembam. Tako se je rodilo prizadevanje za oblikovanje mrež lokalnih skupnosti.

Razvoj kraja s sodelovanjem skupnosti in skupnostnega izobraževanja zahteva od ljudi, da vzamejo svojo prihodnost v svoje roke.

\section{Andragoška poletna šola in skupnostno izobraževanje}

Opazovanje okolja in ljudi v njem ter opazovanje njihovih odzivov na življenjska, osebna in skupnostna, vprašanja nas je privedlo do spoznanja, da ne smemo ostati križem rok in da je morda v skupnostnem izobraževanju ključ do sprememb. Novo ustanovljeno andragoško poletno šolo smo namenoma določili v Ajdovščini. Kraj je s svojo velikostjo in številom ter strukturo prebivalcev ravno pravšnji za to, da tja pomagamo uvesti skupnostno izobraževanje za razvoj kraja in da izkušnje tega pilotnega projekta udeleženci šole morda prenesejo $\mathrm{v}$ druge manjše kraje ali mestne četrti. Kakšna so bila pri tem naša izhodišča?

Skupnostni izobraževalec je lahko v začetku, skupaj z drugimi pobudniki, tisti, ki prisluhne vsem nosilcem krajevnega življenja, malim in srednjevelikim podjetjem, ustanovam, klubom, društvom, novim podjetnikom itd., pa tudi pomoči potrebnim ali osamljenim ljudem, iskalcem zaposlitve, mladim, ki se skušajo vključiti v poklicno in socialno življenje. S takšnimi ukrepi je mogoče kraj in družbo narediti humanejšo, ju približati ljudem. Ustvarijo se vezi med ustanovami in sektorji, ki niso vajeni sodelovanja. Za skupnostni razvoj kraja je to neizogibno potrebno. V skupnostni razvoj vključeni ljudje prispevajo svoje znanje, izkušnje in kulturo in tako uspešno pomagajo:

- mladim, da se vključijo v svet dela in v družbo; pomagajo jim pri šolskih obveznostih, povezujejo učitelje s podjetji, izobražujejo mlade $\mathrm{v}$ zvezi $\mathrm{z}$ iskanjem zaposlitve, za zaposlitveni razgovor, jih prizadeto poslušajo in jim svetujejo;

- iskalcem zaposlitve, da ustanovijo prostovoljske agencije, kjer mlade sprejmejo, jim svetujejo in pomagajo začrtati poklicno pot;

- mladim podjetnikom preučiti dokumentacijo z vidika različnih področij;

- invalidnim osebam, da se vključijo v svet dela, zanje tehnično pregledajo javne in druge zgradbe in naredijo študijo o dostopnosti; 
- karitativnim organizacijam, ki jih vodijo in v njih sodelujejo;

- starejšim ljudem, da se vključijo v okolje, da bolje preživijo in premagajo svojo osamljenost.

Naloga skupnostnega izobraževalca postaja v tem primeru podobna nalogam skupnostnega delavca ali po naše socialnega delavca, ki je usposobljen za animacijo okolja, le da ima skupnostni izobraževalec več znanja in izkušenj s tem, kako se ljudje v skupinah učijo in razvijajo tople solidarnostne vezi v takšni skupini, kar je dobra podlaga za učenje in potreba, če hočemo, da bo posledica takšnega učenja in izobraževanja socialna akcija.

Naloge skupnostnega izobraževalca ali animatorja, ki deluje za razvoj kraja, so, kot že samo ime pove, namenjene razvijanju skupnosti in izobraževanju. Večinoma so sestavljene iz naslednjih faz:

Za razvoj skupnosti:

- ocenitev problemov;

- zbiranje podatkov, analiza potreb;

- navezovanje prvih stikov z ljudmi in analiza njihovih potreb;

- pogajanje o tem, kaj narediti;

- oblikovanje načinov, sistemov, skupin za ukrepanje in vodenje akcij;

- vzdrževanje in usklajevanje sistemov akcije;

- namensko vplivanje;

- zaokrožitev prizadevanj za spremembe.

Če zdaj ta procesni model primerjamo z modelom, ki ga je obdelal Knowles (1972) v zvezi z izobraževanjem odraslih, ugotovimo podobnosti in razlike $\mathrm{v}$ zaporedju faz:

Izobraževanje:

- oblikovanje fizičnega in psihološkega ozračja;

- skupno načrtovanje izobraževanja;

- ugotavljanje potreb;

- ubesedenje ciljev programa;

- načrtovanje zaporedja učnih dejavnosti;

- vodenje učnih izkušenj;

- evalviranje učenja.

Animator skupnostnega razvoja v kraju te faze med seboj preplete, saj gre za delovanje $\mathrm{z}$ dvema hkratnima ciljema, to sta razvoj skupnosti in izobraževanje.

V prvi andragoški poletni šoli smo se posvetili predvsem teoretičnim izhodiščem skupnostnega izobraževanja za razvoj kraja, navezovanju stikov s prebivalci, ugotavljanju in dokumentiranju potreb, prepoznavanju socialnih skupin, ki bi jim lahko pomagali, da se organizirajo v skupnost in začnejo delovati za razvoj kraja.

Med potrebami, ki so se pokazale, je bila potreba po večji pisni komunikaciji v kraju. Značilnost majhnih in večjih krajev v postsocialističnem obdobju je v tem, da sporazumevanje s prebivalci še zmeraj ne poteka drugače kot prek socialnih mrež. Večina informacij je ustnih in nepopolnih. Krajani so izrazili željo, da bi postavili tudi majhno informacijsko središče, kjer bi bilo mogoče dobiti najrazličnejše informacije o problemih, ki zanimajo ljudi. To (majhna sobica) bi moralo biti v središču, opazno, da bi se tam ljudje lahko tudi srečevali in ne le zgolj v gostilnah, kot se to dogaja zdaj. Kraj potrebuje oglasne deske, potrebna je celostna predstavitev Ajdovščne za tujce, ki prihajajo sem. V ta namen bi bilo treba postaviti oglasne deske in organizirati krajane, da bi dobivali informacijske in druge predstavitvene lističe ter brošure na vseh javnih mestih: v predverju občine, v banki, na pošti, v trgovinah, na delavski univerzi, centru za socialno delo, v knjižnici, gostilnah, hotelu itd. Izkazala se je tudi potreba po organizaciji mladih in starejših v skupnosti. Treba je najti skupnostne prostore ali pa šolo odpreti ob večernih urah drugim generacijam. Še naprej bi bilo treba omogočati istovetenje prebivalcev s krajem. Že postavljenim predstavitvenim tablam v castrumu bi dodali mnoga druga znamenja, s katerih bi prebivalci in mimoidoči spoznavali zgodovino svojega kraja. Vloga skupnostnih izobraževalcev bi bila v tem, da naj bi za to povezali med seboj več ustanov in posameznikov.

Druga poletna andragoška šola bo posvečena predvsem animaciji za izobraževanje in delo v skupnosti. Še posebej se bodo udeleženci srečevali s tem, kako pritegniti manj izobražene, ki v institucije in na splošno na uradna mesta ne želijo prihajati in jih je treba najprej »udomačiti«. Manj izobraženi ali funkcionalno nepismeni so danes mnogi ljudje, če upoštevamo dejstvo, da pismenost ni le obvladovanje nekaterih spretnosti, kot je branje, računanje, pisanje itd, marveč je pismenost predvsem to, kako poskrbeti za svoje življenje, kako si v življenju postaviti cilje in jih uskladiti z možnostmi.

\section{Vloga skupnostnega izobraževalca pri oblikovanju skupine}

Skupnostni izobraževalec ne sme postati vodja skupine. Njegova naloga je $\mathrm{v}$ tem, da pomaga skupino oblikovati, da predvidi, na kakšne ovire bi skupina lahko naletela. Njegova naloga je tudi $\mathrm{v}$ tem, da izlušči cilje njenega delovanja in učenja ter da predvidi, kakšne težave bi skupina lahko imela. Pri tem se mu večkrat postavlja vprašanje, ali naj posreduje in spremeni mnenje skupine ali pa naj pusti, da tečejo stvari po svoje in da tako pride do nepopravljivih napak.

Vloga skupnostnega izobraževalca je nadvse pomembna pri postavljanju ciljev, ki naj bi jih skupina dosegla. Skupina, ki svoje cilje jasno dojame, njeni člani pa se z njimi strinjajo, bo bolje delovala na pomembnejših področjih, kot so pridobivanje članov, sredstev, razporejanje ciljev in določanje rokov za njihovo doseganje ter za izpolnitev nalog.

Skupina ima lahko takšne cilje:

- da v razpravo o vprašanjih soseske, kraja ali socialne skupine vključi čim večje število ljudi;

- da predstavlja interese soseske, četrti ali kraja in omogoča ljudem, da svoje interese prepoznajo;

- da združi in predstavlja interese posamezne socialne skupine v kraju;

- da vodi posamezen projekt oziroma nadzoruje ukrepe in opravlja za ljudi storitve;

- da vodi dejavnost v zvezi s problemi, ki se nanašajo tudi na večje upravno-geografsko področje.

Namen skupine pa ni zmeraj enak in se z razvojem, učenjem in delom spreminja. Tako se spreminja tudi njena struktura. Skupine, ki se izobražujejo in delujejo v skupnosti, gredo večinoma skozi tri faze: začetno, organizacijsko, fazo izpolnjevanja nalog in fazo, v kateri skupina preživi ali odmre.

V kraju lahko za njegov razvoj delujejo najrazličnejše, imenujmo jih samoiniciativne skupine. Sem se uvrščajo:

- skupine za samopomoč, ki jih vodijo tisti, ki imajo sami kakšen problem, vendar ga bolje dojamejo in rešijo v skupnosti, na primer zadruge, materinske skupine, skupine za matere samohranilke itd.;

- socialno-varstvene skupine, ki opravljajo storitve za starejše ljudi, na primer sosedska pomoč ali vodenje nekakšnega centra za socialno delo;

- predstavniške skupine, ki jih izvolijo ljudje in so odgovorne skupnosti; 
- skupine za doseganje enakih pravic in možnosti za vse, ki branijo interese raznih ranljivih skupin, kot so disleksični otroci, matere samohranilke, iskalci zaposlitve itd.;

- akcijske skupine ali skupine za politični pritisk, ki si zastavijo za cilj akcije, za katere menijo, da so v interesu cele skupnosti, organizirajo pa se same;

- skupine za povezovanje, to niso prave skupine, organizirane $\mathrm{z}$ animatorjevo pomočjo, marveč jih ustanovi občina, njihov namen pa je, da svetujejo ljudem in prisluhnejo njihovim potrebam;

- tradicionalne organizacije so tiste skupine, ki obstajajo že dlje časa, na primer gasilsko društvo, ženska in moška društva, klubi itd., v Ajdovščini so to lovska družina, planinsko društvo itd.;

- skupine za druženje ljudi v kraju obstajajo zato, da organizirajo družabna srečanja, to so na primer skupine sostanovalcev, ki organizirajo izlet na morje, pa vse do skupin organizatorjev množičnih srečanj, športne lige in konjičkov;

- ideološke skupine, to so politične ali verske skupine, ki se pri reševanju problemov podrejajo svoji filozofiji in svojim pogledom.

Večina skupin ima na začetku malo članov. Vprašanje, ki ga mora izobraževalec zastaviti je: zakaj želite veliko članov? To skupinam pomaga, da vedo, kaj lahko pričakujejo od svojih članov, in da razmislijo o tem, kako bodo morebitni člani delovali. Več članov namreč lahko opravlja več dejavnosti. Bolj se zavedajo problemov, ki tarejo ljudi. Bolje predstavljajo ljudi. Močnejši so pri izpolnjevanju akcij. Lahko zberejo več denarja, skupaj imajo več spretnosti, pomenijo več »človeških virov«.

Vendar glede števila članov v skupinah ni pravil. V skupini so lahko le trije člani, lahko pa skupina preraste v društvo, zvezo ali celo ustanovo. Ni pa treba, da so vsi somišljeniki člani skupine. Takšen primer je skupina, ki izdaja krajevni časopis.

Pretok informacij, še posebej v velikih skupinah, naj bo velik. Velike skupine potrebujejo stalen »news letter«, poročila o izvršnih in drugih srečanjih. Tem pisnim metodam se lahko pridruži še ustno sporočanje o skupini. Vsak član skupine lahko o napredovanju skupine obvesti tri ali štiri druge člane, ki stanujejo v njegovi bližini.

Nekatere skupine niso uspešne, in sicer ravno zato, ker ni pretoka informacij, osebnega stika med člani ali člani in izvršnim odborom. Včasih se osebni stik ustvarja tudi z mesečnim osebnim pobiranjem članarine. Skupine, ki so se že oblikovale in dosegle notranjo trdnost, večinoma ne marajo novih članov. To je seveda v nasprotju z željo, da bi skupina delovala za širšo skupnost, zato se mora temu skupnostni izobraževalec upreti.

Kadar se skupine močno povečajo, je boljše, da imajo napisan statut. Če skupina nima statuta, ne more reči, da v očeh drugih zares obstaja. Naloga izobraževalca odraslih ali njegove ustanove je, da pripravi neke vrste obrazce ali napotke za pripravo statuta.

Lastništvo prostorov ali stalnega prostora za sestajanje je zelo pomembno, psihološko in tudi z vidika delovanja skupine. Skupnostni izobraževalec se mora tega zavedati.

Skupnostni izobraževalec lahko pomaga tudi pri organizaciji krajevnega zbora ljudi. Namen takšnega zbora je:

- ugotoviti mnenja ljudi v posamezni soseski ali četrti;

- določiti vprašanja, dobiti potrditev, zamisli za akcijo;

- izrabiti srečanje za ustanovitev društva;

- organizirati in okrepiti obstoječo skupino, jo narediti bolj reprezentativno v očeh drugih;

- pojasniti, kako napreduje dejavnost in dobiti podporo za nadaljnje delo;
- pokazati, da so zahteve in predlogi dobili široko podporo, in to uporabiti, da se dokaže, da je skupina vredna pozornosti;

- da povabijo predstavnike oblasti;

- da skličejo letno skupščino društva.

$\mathrm{V}$ postsocialističnih deželah se posamezniki ne znajo dobro organizirati, zato je vloga skupnostnega izobraževalca tudi v tem, da jim da osnovno znanje iz organiziranja skupine, skupinske dinamike, priprave »delovnega načrta, strateškega načrtovanja«, pisnega in ustnega sporazumevanja, pogajanj z oblastjo. Pomagati jim mora, da si pridobijo vire učenja in informacij. Predvsem pa je njegova vloga $v$ tem, da preudarno izbere cilje in jih niza $v$ takšne sklope ter stopnje, da jih je mogoče doseči in da skupina, kadar se ozre nazaj, vidi napredek in prehojeno pot. Nezamenljiva pa ostaja vloga izobraževalca pri animaciji ljudi za delo in učenje.

\section{Sklepne misli}

Skupnostnega izobraževanja za razvoj kraja, takšnega, pri katerem se posamezniki, skupine, podjetja in ustanove povezujejo med seboj in se skupaj učijo, pri katerem lokalne oblasti navezujejo stike med seboj in z ljudmi v kraju, torej skupnostnega izobraževanja, pri katerem sodelujejo javni, zasebni in civilni sektor za dosego skupnega cilja, to je za boljšo podobo kraja in boljše življenje v njem, pri nas še ne poznamo. Nasprotno. Ker se srečujemo z velikim številom sprememb, je dokaj razumljivo in naravno, da se zatekamo k centralizaciji. Uravnotežen razvoj države in njenih regij pa zahteva prenos pobud, odločanja in delovanja na lokalno raven in med ljudi. Država ne more zadovoljiti različnih in večznačnih potreb ljudi, ki nastajajo v današnjem času. Če želi ohraniti svoje ravnovesje, bo morala prepustiti ljudem, da poskrbijo sami zase, se oprejo nanjo, nase, pa tudi na delovanje ter izobraževanje v skupnosti.

Dušana Findesien

skupina Logos - jezikovno izobraževanje

\section{Liferafurm}

Caille, A. in drugi: Muke države blaginje, v: Le debat, št. 89, marec-april 1996, Gallimard, Pariz, str. 4-71.

Hauteceour, J. P.: Alpha 94, Culture Concepts, Toronto 1994.

Thomas, D. N.: Skills in Neighbourhood Work, Basic Skills, The AlBSu Magazine, London.

Poster, C.: Community Education in the Western World, Routledge, London 1990

Šmidovnik, J.: Lokalna samouprava, Cankarjeva založba, Ljubljana 1995. 